\title{
Older People's Mobility: Segments, Factors, Trends
}

\author{
Haustein, Sonja; Siren, Anu
}

Published in:

Transport Reviews

Link to article, DOI:

10.1080/01441647.2015.1017867

Publication date:

2015

Document Version

Early version, also known as pre-print

Link back to DTU Orbit

Citation (APA):

Haustein, S., \& Siren, A. (2015). Older People's Mobility: Segments, Factors, Trends. Transport Reviews, 35(4), 466-487. https://doi.org/10.1080/01441647.2015.1017867

\section{General rights}

Copyright and moral rights for the publications made accessible in the public portal are retained by the authors and/or other copyright owners and it is a condition of accessing publications that users recognise and abide by the legal requirements associated with these rights.

- Users may download and print one copy of any publication from the public portal for the purpose of private study or research.

- You may not further distribute the material or use it for any profit-making activity or commercial gain

- You may freely distribute the URL identifying the publication in the public portal

If you believe that this document breaches copyright please contact us providing details, and we will remove access to the work immediately and investigate your claim. 
Older people's mobility: segments, factors, trends

Sonja Haustein*

Department of Transport, Technical University of Denmark,

Bygningstorvet 115, DK-2800 Kgs. Lyngby, Denmark

Tel.: +4545256519

E-mail: sonh@transport.dtu.dk

Anu $\underline{\text { Siren }}$

The Danish National Centre for Social Research,

Herluf Trolles Gade 11, DK-1052 Copenhagen, Denmark

Tel.: +4533697753

E-mail: anu@sfi.dk

*Corresponding author

\section{Acknowledgements}

A part of the work for this article was conducted within Work Package 1 of CONSOL, "CONcerns and SOLutions - Road Safety in the Ageing Societies" supported by the European Commission under Grant Nr. MOVE/C4/SUB/2010-125/SI2.601704/CONSOL (contract period: 2011-2013). The authors would like to thank all CONSOL partners for contributing to the collection of literature, constructive comments and discussions. 


\title{
Older people's mobility: segments, factors, trends
}

\begin{abstract}
The expanding older population is increasingly diverse with regard to, for example, age, income, location, and health. Within transport research, this diversity has recently been addressed in studies that segment the older population into homogeneous groups based on combinations of various demographic, healthrelated or transport-related factors. This paper reviews these studies and compares the segments of older people that different studies have identified. First, as a result of a systematic comparison, we identified four generic segments: (1) an active car-oriented segment; (2) a car-dependent segment, restricted in mobility; (3) a mobile multi-modal segment; (4) and a segment depending on public transport and other services. Second, we examined the single factors used in the reviewed segmentation studies, with focus on whether there is evidence in the literature for the factors' effect on older people's travel behaviour. Based on this, we proposed a theoretical model on how the different determinants work together to form the four mobility patterns related to the identified segments. Finally, based on current trends and expectations, we assessed which segments are likely to increase or decrease in future generations of older people and what should be done to support the multi-optional and independent mobility of older people.
\end{abstract}

Keywords: Segmentation, Older road users, Ageing, Demographic Change, Transport, Mobility, Gender 


\section{Introduction}

According to Eurostat projections (Lanzieri, 2011), the number of those aged 65 and over, as a share of the population aged 20-64 years, will double between 2010 and 2050 in Europe. This development will affect almost every aspect of society, including the transport sector (Coughlin, 2009). It is expected that as a demographic group, older people will have an increasing impact on the transport system, resulting both from the increase in absolute and relative number of older persons and also from the socio-cultural and economic characteristics of these new cohorts of older persons. Nevertheless, the ageing population is increasingly diverse with regard to, for example, age, functionality, socio-economic resources, spatial location and household structure. This diversity has been addressed in a number of studies that no longer consider the older population as a homogeneous group but divide them into meaningful segments, in order to either derive more targeted measures based on their specific needs (e.g., Marin-Lamellet \& Haustein, 2014), improve transport modelling (e.g., Hildebrand, 2003) or to devise scenarios for older people's future mobility (e.g., Aigner et al., 2010; Siren \& Haustein, 2013).

In this paper, we reviewed these segmentation studies and compared them not only with regard to the method applied but also, and in particular, with regard to the identified segments. We grouped the identified segments to integrate the findings of all reviewed studies and extracted general mobility patterns of older people across age groups and regions. Taking the reviewed segmentation studies as a starting point, we then examined in more detail the single factors that have been used to segment the older population and reviewed the literature for evidence that these are relevant factors of older people's mobility patterns, and if so, whether they are expected to have a direct or indirect effect on their mobility patterns. Based on a synthesis of these findings, we proposed a hypothetical model that integrates the most relevant determinants of older people's mobility patterns and their interrelations. Finally, we suggested, based on assumed changes in the single factors, which mobility patterns are likely to increase or become less important in future generations of older people.

\section{Segments of older people and their mobility patterns}

We reviewed studies with a segmentation approach on older people and travel behaviour, published since 2000. The review includes scientific papers and project reports published in English and German ${ }^{1}$. In the following, we first provide some background on the segmentation method and then describe the studies in more detail. Finally, we synthesise the results from the studies by suggesting a grouping based on a categorisation of the segments in the reviewed studies.

\subsection{Segmentation in the transport research literature}

Segmentation approaches in the transport research literature can be distinguished by the type of factors they are based upon. These are traditionally behavioural, demographic, spatial, or attitudinal factors (see Haustein \& Hunecke, 2013). In the segmentation of older people, the different categories (e.g.,

\footnotetext{
${ }^{1}$ French, Scandinavian, and Czech literature was also researched but without identifying any segmentations of older road users.
} 
demographic and attitudinal factors) were more often combined, possibly because of a stronger focus on practical rather than on theoretical outcomes.

The literature additionally differentiates between a priori and post-hoc segmentation approaches (Wedel \& Kamakura, 1998). In the case of an a priori segmentation, the constituent variables of the segments, as well as the segment profiles, are well-defined so that each respondent can be clearly assigned to one of the postulated segments. In post-hoc segmentation, groups are specified on the basis of empirical results. Individuals are grouped according to their similarity across a set of variables, and in most cases, the segmentation is the result of a cluster analysis. When clustering, it is normally not clear beforehand how many clusters are most appropriate and different cluster solutions are usually compared with regard to both methodological criteria and the interpretability of the resulting clusters.

\subsection{Segmentation of older road users}

Table 1 lists the segmentation studies included in this review and provides details on the method of segmentation, variables used for segmentation, and sample characteristics. As the table reveals, all but one study is based on cluster analysis. By contrast, there is a great variety with regard to the sample characteristics and variables used for segmentation. Only one study is from North America (Hildebrand, 2003) and the others are from Europe.

\section{---- Insert Table 1 ---}

The only study with an a priori approach was the Austrian study by Aigner-Breuss et al. (2010), which developed mobility scenarios for ruralists above 55 years. The study differentiated between three behaviourally homogeneous groups based on their car use: (1) older people who predominantly used a private car (66\%), (2) selective car users, who chose the mode of transport that best suited a given situation (19\%), and (3) older people without access to a private car (15\%). People in the third group were most restricted with regard to financial resources, education, and mobility while the second group had the best socio-economic resources.

In the project SZENAMO, older people were clustered based on health, household structure, and occupation resulting in three segments: "Fully mobile seniors", "Slightly physically impaired seniors", and "Highly physically impaired seniors" (Bell et al., 2010). The three groups significantly differed with regard to age, out-of-home-mobility, activities, and the subjective evaluation of their mobility options. Fully mobile seniors were often still working, younger, and more active and preferred the car as transport mode, while slightly impaired seniors were mostly retired, satisfied with their health state, hardly suffered from physical impairments and preferred walking and cycling, while the highly impaired seniors most often lived alone, had more physical restrictions, were most unsatisfied with their health, and most often used public transportation and special transport.

In a German study, Haustein, Hunecke, and Kemming (2008) used mobility specific attitudes as well as car access and age to create six distinct segments of older people. The study was based on a sub-sample of a larger sample with a broader age-range. In a later study that only focused on older people, Haustein (2012) included more factors that were assumed to be especially relevant for older people's mobility. Here, a set of regression analyses was used to first identify the most relevant determinants of older people's travel behaviour. As a result, different mobility-related attitudes (see Section 3.6), car availability, accessibility of 
facilities by walking, income, and the size of the social network were used to identify the following four segments by cluster analysis: "Affluent mobiles": a better-off, highly mobile, car-oriented type; "Selfdetermined mobiles": a type, open to the use of all modes of transport; and two more restricted types with regard to mobility, health and income: one of them dependent on the car ("Captive car users"), and the other on public transport ("Captive PT-users"). Although based on a different regional sample, the resulting segments reflected the ones in the previous study except for the public transport and bike orientations being less finely distinguished.

Based on socio-demographic variables, Hildebrand (2003) identified six distinct lifestyle clusters, which differed significantly in their mobility behaviour and activity engagement patterns. In contrast to the European studies, all clusters used a car for the majority of trips; the average percentage of trip by car was $86 \%$. The spectrum spanned from "Workers" who had 3.9 daily trips of which $93 \%$ were conducted by car to "Mobility impaired" with 1.7 daily trips of which $56 \%$ were done by car - almost in all cases as a passenger. The Mobility impaired was the only group for which public transport played a relevant role (16.5\% of trips); as members of this group were more often handicapped, not licensed, had lower incomes, and were older, this was probably not by choice.

In the EU project GOAL (Mandl, Millonig, \& Friedl, 2013), five clusters of older people were differentiated based on variables related to physical and mental health and socio-demographic variables as included in the SHARE database (SHARE project, 2014). The draft profiles were completed based on additional surveys and ranged from "Fit as a Fiddle" - the youngest, healthiest, and most active groups to "the Care-Full" - the oldest, most fragile, and least active group. The group "An Oldie but a Goodie" was also a group advanced in years that was, however, quite healthy, satisfied, and active, while with the group "Hole in the Heart" was a comparable young group that was strongly limited in activities due to mental and physical problems.

In the European MOBILATE project (Mollenkopf et al., 2004), older people were clustered according to their mobility behaviour and satisfaction with mobility. As a result, four subgroups were identified spanning from high to low mobility options and satisfaction. Car use, health status, financial and educational resources, as well as percentage living in an urban area decreased gradually from group one to four, indicating that clusters differed more quantitatively than qualitatively.

Finally, Siren and Haustein (2013) clustered a sample of Danish baby boomers (belonging to 1946 and 1947 cohorts) based on their future expectations related to the use of different modes of transport, general living conditions, and their level of dependency on others. They identified three segments: the "Independents" who expected to use individual modes, i.e., driving, cycling and walking and were most optimistic about not depending on others; the "Flexibles" who expected to use all transport modes but using the car to a lesser extent and were open to the use of different mobility services; and the "Restricted" who expected to be most restricted in transport and services use and more dependent on others.

\subsection{A synthesis of existing segmentations studies}

Certain aspects were used in all eight studies to describe the resulting segments: (1) the car-orientation, expressed either as the percentage of trips made by car, a general preference for the car and/or specific attitudes towards the car; (2) the activity level, expressed for example in the number of activities or mobility rate; (3) socio-economic resources, provided as personal or household income and in most cases level of education; (4) health, either a subjective evaluation, the existence of specific symptoms or diseases, 
mobility restrictions or being handicapped; and (5) gender, provided either by the exact share of men/women in a segment or an indication of overrepresentation of men or women.

In order to group the identified segments by shared characteristics, we transferred the information provided for each segment from the different studies into three categories: as above average $(+)$, average (0), or below average (-) in relation to the total study sample. We then sorted the segments according to the codes in each category (Table 2). As a result, we could identify four patterns: The most distinctive two patterns consisted of segments that ranked either above or below average in all five categories. These were, on the one hand highly mobile car-oriented people with high incomes and education and good health who were more often male ("Affluent mobile drivers"), and on the other hand those that were restricted in all domains, who mostly depended on public transport or walking (if their health status allowed) or on getting a lift from someone, and who were more often female ("Transport service dependent seniors"). The more interesting patterns were probably the two between these extremes. The first one was similar to the group of service dependent segments with one main difference: the high car-orientation. People in this group ("Car-dependent seniors") relied on the car while other transport modes were not regarded as a relevant alternative and often strongly refused because of health restrictions, lack of accessibility, and/or negative attitudes, for example towards public transport. Socio-economic resources were - with one exception - restricted and gender was mostly equally distributed. The last segment was mainly characterised as active or very active without being particularly car-oriented ("Mobile multi-modal seniors"). People in this group, especially in the case of the younger segments, often had car access but chose the car only for selected trips and otherwise chose the transport mode most suitable for a given situation taking practical but also health or environmental aspects into account. This was the only group for which cycling also played a relevant role (when this was examined). Socio-economic resources and health were average or above (with one exception) and both genders were equally represented in this group. A more detailed differentiation might be appropriate here with regard to biking or public transport orientation and the specific motives in relation to the use of these modes; however, these aspects were mostly not examined. This group of segments is the most heterogeneous one.

\section{--- Insert Table 2 ---}

Two segments ("Predominant car users" and "Mobile widows") could not be clearly assigned to one of the four groups of segments as they were hybrids between both car-oriented groups as their activity level was average and results regarding resources were also more mixed. In addition, two segments in the group of Transport service dependent seniors ("Captive PT-users" and "Pragmatic PT-oriented") stood out as they were less restricted in their activities despite their dependency on public transport; most of them lived in central districts with good public transport access and were satisfied with their transport options.

When taking into account geographical factors that were, however, not considered in all studies, we found that Car-dependent seniors were overrepresented in rural areas, whereas Mobile multi-modal seniors and, in particular, Transport service dependent seniors were overrepresented in urban areas. Four of six segments in the sole US study (Hildebrand, 2003) fell into both car-oriented groups and the two others into the transport service dependent group, while the Mobile multi-modal group was not represented in the US. Within Europe, the more disadvantaged groups tend to be more strongly represented in Eastern and Southern Europe and the more healthy and active groups in Northern and Western Europe (Mollenkopf et al., 2004), though this interpretation is based on a very limited number of European countries. 


\section{Determinants of older people's mobility patterns}

In this section, we examined the factors that have been used to segment the older population guided by two questions: have the factors been found to be related to older people's mobility behaviour in the literature, and if so, are they assumed to have a direct or indirect effect on mobility? The factors include: age, sex, socio-economic factors (working status, income), household structure, the built environment, car access, health, the social network, and attitudinal factors (cf. Table 1, last column). As outcome variables we focused on mode choice (car use in particular) and activity frequency as the combination of both these variables leads to the four mobility patterns related to the four generic segments we identified based on the reviewed segmentation studies.

\subsection{Individual characteristics}

Age

The concept of age is multidimensional, and there are several ways of defining old age, including chronological age, functional capacity or major life events like retirement or widowhood (Arber \& Ginn, 1991). In this section we focus on chronological age, which has been used as a segmentation factor in several studies (e.g. Haustein et al., 2008; Hildebrand, 2003).

Data from national travel surveys across Europe show that, on average, older people travel less than younger people in terms of trips per day, distance and travel time (e.g., BFS \& ARE, 2007; INFAS \& DLR, 2010; $\rceil \varnothing I, 2011)$. Compared to other adult age groups, older people have a higher share of walking and public transport use and they drive a car less frequently (e.g., INFAS \& DLR, 2010; OECD, 2001; TØI, 2011), which is related to lower licensing rates and car access and might thus be different in future cohorts. The general trend of decreasing travel activity - in particular car use - with increasing age is rather universal, but the specific parameters differ somewhat between European countries, reflecting the differences in, for example, driver licensing rates, socio-economic, and infrastructural factors. Figure 1 shows the distances travelled with different transport modes in selected European countries and how they decline with increasing age (though based on cross-sectional data).

\section{--- insert Figure 1 ---}

Rather than chronological age per se, the different variables that are related to age, such as decreasing functionality and health, the occurrence of specific life events in older age, are likely to modify mobility behaviour. Factors such as widowhood, living in a single-person household, and retirement, are likely to occur in later life and are all related to decreasing car access. Nevertheless, the variability between individuals is great, especially with regard to physical and mental health in later life, and thus, age per se can only be regarded as a weak predictor of older people's mobility.

Gender

While gender has been explicitly included as a segmentation factor only by Hildebrand (2003), most of the identified segments in the different studies were related to gender. This can be explained by gender being strongly related to other factors relevant for mobility behaviour, especially car access, being licensed as a 
driver, and income with women being disadvantaged across all factors. In addition, as a consequence of their longevity compared to men, the majority of the oldest and thus the physically most fragile population is female.

Although car ownership among older women has significantly increased during the past decades (e.g., Hjorthol, Levin, \& Siren, 2010), older women are still less likely to hold a driving licence compared to men (e.g., Hjorthol et al., 2010; Frändberg \& Vilhelmson, 2011; Li, Raeside, Chen, \& McQuaid, 2012; Siren \& Haustein, 2013). Older women are also more likely to give up driving prematurely; that is, when they are still fit to drive (e.g., Bauer, Adler, Kuskowski, \& Rottunda, 2003; Hjorthol, 2013; Siren, Hakamies-Blomqvist, \& Lindeman, 2004; Siren \& Haustein, 2014b; Transek, 2005).

There are notable gender differences in modal choices. Older women walk more often and travel more by public transport, whereas older men drive more frequently. When travelling in a personal vehicle, older women are more often passengers and not drivers (Hanson \& Hildebrand, 2011; Li et al., 2012;

Rosenbloom, 2006; Siren \& Hakamies-Blomqvist, 2006) and not all gender differences in mode choice can be explained by differences in licensing and car availability (Haustein et al., 2014; Le Vine \& Jones, 2012).

Women are mostly found to make fewer daily trips, especially by car (e.g., Li et al., 2012; Mollenkopf et al., 2004; Rosenbloom, 2006; Siren \& Hakamies-Blomqvist, 2004). This has been interpreted as indicating a gender-related disadvantage in mobility, which is further supported by findings showing that older women depend more on others for their personal travel needs (Siren \& Hakamies-Blomqvist, 2006), are more affected by loss of a spouse with regard to unfulfilled travel needs (Ahern \& Hine, 2012) and experience more unmet travel needs than men (Hjorthol, 2013; Scheiner, 2006; Siren \& Hakamies-Blomqvist, 2004, 2006).

Older women also report more difficulties with all transport modes than older men (Li et al., 2012). Their transportation problems are significantly related to income and income-satisfaction, while this is not the case for older men (Dubuis, Weiss, \& Wolfson, 2007). Thus, missing financial resources are more likely a restricting factor in older women's rather than older men's mobility (e.g., Rosenbloom \& Winsten-Bartlett, 2002; Siren \& Hakamies-Blomqvist, 2004). An additional factor limiting especially older women's mobility is the perceived lack of safety and security (Davidson, 1999; Haustein \& Kemming, 2008; Pain, 1997), also including a higher fear of falling (Scheffer, Schuurmans, van Dijk, van der Hooft, \& de Rooij, 2008).

\subsection{Socio-economic factors}

Income

Generally, it has been found that older people with a higher income make more trips (Tacken, 1998), are more likely to drive (Kim \& Ulfarsson, 2004), and less likely to use public transport (Su \& Bell, 2009). Financial concerns are also one reason, among others, for older people to stop driving a car (HakamiesBlomqvist \& Wahlström, 1998; Siren \& Haustein, 2014b).

In a qualitative study by Knight et al. (2007), many participants with lower incomes reported that transportation costs restricted both the amount of travel and the mode choice. Nilsson, Avlund, and Lund (2011), in a longitudinal setting, found that the combination of low financial assets and poor social relations significantly increased older people's mobility limitations. 
In multivariate analysis, income proved to have a significant effect on older people's leisure activity diversity and leisure distance (Scheiner, 2006). While income was not significantly related to leisure activity frequency, unfulfilled activity wishes or leisure satisfaction in Scheiner's study (2006), Haustein (2012) found that it was related to the frequency of other activities (work, shopping and private errands) and car use even when controlling for other factors, such as car availability. Predicting the probability of having a transportation deficiency, Kim (2011) showed a significant effect of income, while Dubuis et al. (2007) found socio-economic variables only associated with women's but not with men's transportation problems.

All in all, the results on socio-economic resources are not unanimous. Despite the use of different research methods variations in the welfare system and the infrastructural conditions in countries where the respective studies were carried out might play a relevant role. Depending on the quality of available alternatives to a private car and the effort used to prevent social exclusion, for example, by providing subsidised access to public transport (where available) or taxis (where not), not having enough money to own and maintain a car may or may not have negative consequences on mobility.

\section{Employment status and retirement}

In cross-sectional studies, employment status was neither found to have a significant effect on older people's leisure activity frequency (Haustein, 2012; Haustein et al., 2008; Scheiner, 2006) nor on their mode choice (Haustein, 2012; Haustein et al., 2008) when income, car access, and other related variables were controlled for. In contrast, being still employed was found to increase non-leisure trips (Haustein, 2012), the total amount of distances travelled (Haustein et al., 2008), and the amount of unmet mobility wishes (Scheiner, 2006) - the latter probably because of a more restricted time budget of the working population. A life course perspective can be helpful in understanding the transport related implications of retirement. Following a group of Danish baby boomers who either continued or stopped working over a 2year period, Siren and Haustein (2014a) showed that frequent car use was more common amongst those who were still working, whereas those who retired significantly decreased their overall mileage, although car use for certain leisure purposes actually increased after retirement. Interactions of various factors within transitions, though, have to be considered. Health has an effect on retirement (see for example Deschryvere, 2005) and retirement may have an impact on health and consequently travel patterns. However, recent findings on the impact of retirement on cognitive function and health have been contradictory (Bingley \& Martinello, 2013; Bonsang, Adam, \& Perelman, 2012; Mazzonna \& Peracchi, 2012; Rohwedder \& Willis, 2010).

\subsection{Living form and environment}

Household structure and related transitions

In segmentation studies, people in couple households were generally overrepresented in the more mobile and less restricted segments while persons in single households were among the most restricted segments. This may, however, be explained by the correlation of living alone with age, health, and car-access, and female gender. To say something about the specific effect of living in a single person household, one needs to control for these confounding variables.

Scheiner (2006) found that being older than 70 years in combination with living together with a partner reduced the level of mobility, when other factors, such as health or car access were controlled for. He 
explained this finding with two factors: first, older people living alone are more compelled to satisfy their needs for social contact outside the home (cf. Kunert, 1994; Schwanen et al., 2001). Second, the likelihood of being a care-giver for a partner increases with advancing age and may reduce the activity frequency outside the home. In line with Scheiner's (2006) results it was found that older people's leisure activities (Haustein, 2012) and general mobility (Evans, 2001; Schwanen et al., 2001) increased with decreasing household size/living alone when other factors, such as age and gender, were controlled for. Thus, it is most likely not living in a single household that reduces mobility but the fact that people who live in single households are older, more often widowed, female, and less healthy.

Few studies have specifically investigated the transition from a two to a one person household and the implications for out-of-home mobility. While Bell could not identify a change in mobility before and after the transition (2010), in a study by Waara and Stjernborg (2010) the majority of the respondents (59\%) stated that the transition had a positive effect on their possibilities for travel, mainly because of reduced responsibilities in the household, gained independence and extra time. In contrast, $41 \%$ experienced a negative outcome on their possibilities to travel because of the transition, especially with regard to depending on public transport and on catching a ride with someone else.

Built environment

Although variables related to the built environment have only been used in one study as a factor for segmentation (Haustein, 2012), segments identified in most reviewed studies were related to the built environment: car dependent seniors were more often found in rural districts and multi-modal and service dependent senior in urban districts.

This is not surprising as older urban residents undertake a higher percentage of their trips using public transport and walk more often, whereas people in rural areas use the car more often (e.g., INFAS \& DLR, 2010) and population density has a negative effect on older people's likelihood to use a car (Evans, 2001; Kim \& Ulfarsson, 2004).

Differences between rural and urban residents are, however, much more pronounced for non-drivers (Schwanen, Dijst, \& Dieleman, 2001). In rural areas, car access is often a precondition for independent life (cf. Ahern \& Hine, 2012; Hanson \& Hildebrand, 2011). In line with this, Mollenkopf (2002) showed that satisfaction with mobility options in rural areas is-among other factors-determined by car access, while this is not the case in urban areas. However, urbanity was found to have a lower car-reducing effect for older than for younger people (Figueroa, Nielsen, \& Siren, 2014; Haustein, Nielsen \& Siren, 2014).

With regard to unfulfilled mobility needs, studies from Finland (Siren \& Hakamies-Blomqvist, 2004) and Norway (Hjorthol, 2013) found stronger effects of the settlement structure than studies from Denmark (Haustein \& Siren, 2014) and Germany (Scheiner, 2006). This indicates that in countries with higher population density, "rural" has a different quality and effect than in low density countries. Unlike variables such as chronological age or gender that are rather easy to operationalise, the concepts of rural and urban areas can vary greatly with regard to density, availability of facilities and public transport. In addition, residential self-selection effects may interfere: people who decide to live in rural areas likely differ from urban residents on several characteristics (e.g., Aditjandra, Cao, \& Mulley, 2012; Cao, Handy, \& Mokhtarian, 2009; Handy, Cao, \& Mokhtarian, 2005; Scheiner \& Holz-Rau, 2007). 
The importance of the built environment for successful aging is stressed by the results of a British longitudinal study showing that living in a deprived neighbourhood is associated with cognitive decline independent of socio-economic factors (Lang et al., 2008) and a recent US study indicating that walkable neighbourhoods can mitigate cognitive decline (Watts et al., 2014).

\subsection{Car access}

Car access has been found to be associated with better physical and mental health and well-being (Banister \& Bowling, 2004; Ellaway, Macintyre, Hiscock, \& Kearns, 2003; Fonda, Wallace, \& Herzog, 2001; Köpke, Deubel, Engeln, \& Schlag, 1999; Macintyre, Hiscock, Kearns, \& Ellaway, 2001; Marottoli et al., 1997; Siren \& Haustein, 2014c). On the one hand it is argued that the car enables older people with physical limitations to still live independently and participate better in normal daily activities (Siren \& Hakamies-Blomqvist, 2004, 2009). On the other hand, it is pointed out that it is the more healthy and active older people who (still) own a car (Scheiner, 2006). It can be assumed that the cause-effect relationship between health and car access is bidirectional. Apart from health, car access (and use) is also linked to other factors reviewed here, especially the built environment, household structure, and gender as outlined in the respective sections.

That car access is related to mode choice is obvious. With regard to met and unmet activities, results are less clear: Haustein (2012) showed that car availability was related to the number of leisure activities even when controlling for relevant background variables, while this was not the case in a study by Scheiner (2006), who additionally found no significant relation to the existence of unmet leisure needs or to leisure satisfaction. By contrast, two more recent studies demonstrated a significant effect of not having a driving licence or a car on unfulfilled mobility needs, though controlling for similar factors as did Scheiner (Haustein \& Siren, 2014; Hjorthol, 2013). Differences may be partly explained by different levels of car dependency in the study areas, which makes the car more or less essential for fulfilling older people's mobility needs.

\subsection{Health}

The participation in social and productive activities contributes to older people's health, cognitive functioning, and well-being (Engelhardt, Buber, Skirbekk, \& Prskawetz, 2010; Menec, 2003; Scheiner, 2004; Siegrist \& Wahrendorf, 2009), while health restrictions reduce older people's activity frequency (e.g., Scheiner, 2006; Smith \& Sylvestre, 2001) and increased their unfulfilled activity wishes (Haustein \& Siren, 2014; Hjorthol, 2013; Scheiner, 2006). The subjective health status and feelings of control (mastery, selfefficacy) appear to be more relevant for the fulfilment of activity wishes than the "objective" health state, measured for example by specific physical symptoms (Haustein \& Siren, 2014; Mandl et al., 2013). As outlined in Section 3.3. and 3.4, older people's health is affected by the built environment and car access and also thereby influences mobility.

\subsection{Social network}

The social network seems to play an important role in later life (e.g., Scheiner, 2006). We see two main reasons for that: First, for persons in the post-retirement phase, social and leisure activities form a larger share of their travel and thus the social network and social engagement may determine their travel to a larger extent than for working people. As grandparents they, for example, play a relevant role in chauffeuring their grandchildren (Siren \& Haustein, 2014a). Second, for older people restricted in their 
mobility, the social network is crucial in order to conduct any out of home activities. Without the option to drive, older people often depend on their social network to get a lift (e.g., Ahern \& Hine, 2012).

Scheiner (2006) found a strong social network to be related to older people's activity frequency, diversity, leisure distance, and leisure satisfaction. Haustein (2012) showed a significant impact of the network size on the number of activities conducted by older adults. In both studies other relevant factors, such as age, health, and car access, were controlled for.

\subsection{Attitudinal factors}

The only two segmentation studies that included attitudinal factors were the studies by Haustein (2012) and Haustein et al. (2008). The factors in both studies were mainly derived from the Theory of Planned Behaviour (Ajzen, 1991) and included social norm, perceived behavioural control, and attitudes in relation to functional and symbolic aspects of different transport modes. In addition, perceived mobility necessities (PMN; Haustein \& Hunecke, 2007) were added accounting for effects of the actual living situation on modal choices and activity frequency. In both studies, factors were selected for segmentation when they showed a significant effect on at least two different aspects of mobility behaviour: mode choice, activity frequency, or distances travelled. In both studies, this was the case for the following factors: PMN, public transport control, cycling attitude, and weather resistance. Older people with high PMN were found to have more non-leisure trips, a higher percentage of trips by car and less by public transport (Haustein, 2012; Haustein et al., 2008). Public transport control measures how easy or difficult individuals perceive the use of public transport and whether they feel restricted in their autonomy when using public transport instead of the private car. Public transport control was found to reduce the percentage of trips by car and to increase public transport use (Haustein, 2012; Haustein et al., 2008). With "car dependency", a similar construct was found to have a significant impact on vehicle miles driven in a study by Cao, Mokhtarian, and Handy (2007). A positive cycling attitude and the willingness to use a bicycle in all weather conditions ("whether resistance") were found to be especially relevant for the percentage of trips by bike, while weather resistance also reduced the trips by car (Haustein, 2012; Haustein et al., 2008). Haustein (2012) additionally included "walking attitude", which was related to fewer car trips and more leisure time activities.

While the attitudinal factors described above were found to be relevant factors of older people's mobility in regression analyses, the cause-and-effect relation remains unclear. Within the framework of the Theory of Cognitive Dissonance (Festinger, 1957), it is argued that in the case of a mismatch of attitudes and behaviour, attitudes will be aligned with a behaviour, and this direction of influence was empirically supported by Dobson, Dunbar, Smith, Reibstein, and Lovelock (1978) or Golob (2001). Studies within the framework of the Theory of Planned Behaviour (e.g., Bamberg \& Schmidt, 2001, 2003; Haustein \& Hunecke, 2007), in general only account for attitudes being a predictor of behaviour (mediated by intention), although a feedback loop back from behaviour to the antecedent beliefs is considered by Ajzen (1991).

\section{A theoretical model of older people's mobility patterns}

In Figure 2, we summarise the findings presented in Section 3, and illustrate how we assume factors to work together to form the four mobility patterns related to the identified generic segments in Section 2 .

According to the model, individual characteristics, such as being female and more advanced in age only have an indirect effect on older people's mobility patterns, mediated by the health status, socio-economic 
factors, access to a car, and the size of the social network. An older woman is more likely to be restricted in health, income, and car access and therefore more likely to be a Service dependent senior. For similar reasons a comparably young man is more likely to be an Affluent mobile driver.

The built environment has a bidirectional relationship with transport attitudes, thus accounting also for residential self-selection effects. Transport attitudes, perceived control and demand as well as health can both be cause and effect of specific mobility patterns: A positive cycling attitude will, for example lead to more cycling, and more cycling will further increase a positive cycling attitude, perceived behaviour control and will also have a positive health effect. On the other hand, health restrictions will reduce positive beliefs related to the experience and control of cycling, and thereby reduce cycling. Similarly, access to a car on the one hand increases transport options and decreases unmet mobility needs, while exclusive car use at the expense of the use of active modes may in the long run decrease functionality and health. In such a scenario, Affluent mobile drivers might evolve into Car-dependent seniors with decreasing health status. Another likely scenario is that Mobile multi-modal seniors evolve into Service dependent seniors when they are forces to cease driving and are not able to cycle anymore. In contrast, developments from less active to more active segments are rather unlikely as well as developments from less to more car-oriented segments.

--- insert Figure 2 ---

\section{The future of older people's mobility patterns}

Due to current and future changes in built, social, and cultural environments that surround older persons' travel, we can expect changes in the mobility behaviour of older persons in the future.

Current changes in the built environment, such as urban sprawl and the withdrawal of public transportation in rural areas (cf. Ahern \& Hine, 2012; Eriksson \& Westin, 2003) are likely to increase older people's car dependency and decrease their public transport control. Recent research on the potential effect of urbanisation on older people indicated that urbanity decreases older people's car use to a lesser extent than younger people's (Figueroa et al., 2014; Haustein et al., 2014), which also points towards an increase of the car-oriented segments.

Social changes include later and less fixed retirement ages, the increased longevity and thus a more ageand health-diverse older population. On the one hand, we will find healthier, wealthier and more active and independent "young" older adults as compared to earlier cohorts; on the other hand, due to longevity, there will be an increasing percentage of people in the oldest age groups, who are more likely to be suffering from chronic diseases, such as depression and dementia. Both trends are likely to have effects, albeit opposing ones, on travel patterns. As women have longer life-expectancies than men, they more often suffer from long-term chronic conditions that hamper physical mobility (Arber \& Cooper, 1999). The life-expectancy gap between the sexes is, however, expected to narrow, which could reverse the growth in single households (Shergold, Lyons, \& Hubers, 2014), and thereby further increase older people's car access and use. 
Cultural effects include that the new generations of older people have different lifestyles than past generations. They have higher expectations for living active and independent and are more demanding consumers of products and services (Kirchmair, 2005). In line with that, they are assumed to maintain more active mobility patterns and hold on to their licences into advanced ages (e.g., Hakamies-Blomqvist, Henriksson, Anund, \& Sörensen, 2005; Hjorthol et al., 2010). Also in terms of lifestyles, a convergence between the sexes can be noticed: women's employment and licensing rates are adjusting to those of men. While increased access to a car does not necessarily imply that the new cohort of older women also drive more (Siren \& Haustein, 2013), in particular the growing group of older women who continue working until advanced aged seem to remain in particularly car reliant (Siren \& Haustein, 2014a).

All in all, we can conclude that a growth of the two predominant car using segments is most likely to occur, with the younger age groups being more likely to belong to the Mobile affluent drivers and the older age groups and ruralists to the Car dependent seniors. In particular, the segment of the Transport service dependent seniors will probably shrink. In the long run this group may to an even higher extent consist of the most disadvantaged people, such as ethnic minority women, as has been demonstrated in the US for the group of non-drivers (Choi \& Mezuk, 2013). In order not to lose a large part of their customers, public transport providers need to make an effort to make their services more attractive for non-captive users and may thereby most likely also serve the group that depend on public transport.

While young adults previously represented one of the most car-oriented age groups, European trends point to a decrease in car use and more multi-modal travel behaviour of young adults, in particular males (e.g., Kuhnimhof, Armoogum, Buehler, Denstadli, \& Yamamoto, 2012; Kuhnimhof, Buehler, Wirtz, \& Kalinowska, 2012). This European trend (if confirmed) is not visible in the majority of older people but rather the opposite, so that we actually find "a strong inverse relationship between age and change in car mileage" (Le Vine \& Jones, 2012, p. 19). The Mobile multi-modal seniors, however, represent both trends: the higher multi-modality found in the young and the higher car-access (as compared to earlier cohorts) of the old generation. In how far they have the potential to become a trend-setter for future generations of older people may also depend on investments in infrastructure, developments of supportive technologies, as well as changes in social norms with regard to the use of different transport modes. The flexibility of this group, its active choice of transport mode to stay in good shape, and openness for services that support their mobility options (cf. Siren \& Haustein, 2013) is likely to make it the most well prepared group for an independent and mobile later life.

\section{Conclusions}

In this study, we demonstrated that, across different European regions and age groups, basically four segments of older people can be distinguished: an active car-oriented segment; a car-dependent segment, restricted in mobility; a mobile multi-modal segment; and a segment depending on public transport and other services.

In contrast to European studies, the Mobile multi-modal segment could not be identified in the only study from the US. This is most likely because of the higher car dependency that North American settlement structures generate, providing less opportunities for the use of active transport modes. Reducing cardependency by providing safe and attractive infrastructure for the safe use of active modes and better 
public transport services can be regarded as a key task to support multi-modal transport patterns. Countries with higher cycling rates (esp. Netherlands, Denmark, and Germany) provide better cycling infrastructure, make driving in cities more inconvenient, and have land-use policies that facilitate mixed use and thereby generate shorter tips that less often require a car (Pucher \& Buehler, 2008). Infrastructural improvements, such as separation between bicyclists and pedestrians, are perceived differently in different subgroups (e.g., Ståhl, Horstmann, \& Iwarsson, 2013) and should thus be promoted in a targeted way. This also applies for courses and activities to increase older people's safe use of public transport and active modes as these services so far mainly reach the current users groups but fail in attracting new user groups (Marin-Lamellet \& Haustein, 2014).

Transport-related technological developments, such as electric bikes, in-car technologies, and driverless cars may offer good opportunities for older people to stay mobile in advanced age. Also here it is important to promote these technologies in a targeted way: While Affluent mobile drivers are generally open to technologies and can probably be attracted for cycling by technologically advanced, exclusive electric bikes that are promoted with attributes like fun and autonomy, the two dependent and more restricted segments might be won by experiencing that electric bikes actually facilitate cycling but probably need a course to gain safety by practising under advise. Promoting in-car technologies as something that facilitate older people's driving might have a negative effect on Affluent mobile drivers, as they probably do not feel old or in need for assistance, while it might be attractive for Car-dependent seniors to prolong their driving careers.

Besides infrastructural and technological improvements and their target-group specific communication also policies should facilitate older people's mobility. In many countries policies are in place that require a specific procedure for older people to renew their licences, although there is no evidence from the literature demonstrating that the benefits from age-based driver screening would outweigh the disadvantages (Siren \& Haustein, 2014d). Instead of policies that hamper older adults to keep the option to drive, we recommend measures that support older people's safe car use, for example by voluntary driver trainings, which have been shown to be effective in improving the ability to master difficult traffic situations at an advanced age (Poschadel et al., 2012). In addition, in particular car dependent seniors should be educated and trained in the use of alternative modes before they have to stop driving to attenuate the consequences of driving cessation (Musselwhite, 2010). The more transport options older people have and practise, the less prone they may be to unwarranted mobility loss, in case one of the options is omitted in later life.

With regard to applying segmentation studies, two aspects appear relevant for future research. First, most reviewed segmentation studies focused on realised activities instead of also considering unrealised mobility. According to recent research, the unmet travel demand is, however, more relevant for quality of life than the actual number of activities (Kolodinsky et al., 2013) and should thus also be considered in segmentation studies. Second, it is unknown how stable the identified segments are over time and this can only be answered by longitudinal studies. Will more active and healthy people remain a member of their segment when they age or will they transfer to a less active segment as a result of reductions in health and functionality? Here, also the development of supporting transport and non-transport technologies may play a relevant role in allowing older people with limited functionality to keep an active life style (Shergold, 
Lyons, \& Hubers, 2014). That similar segments have been identified across a variety of regions and age groups suggest that the identified segments will also be found in future generation of older people - but most likely in different sizes. 


\section{References}

Aditjandra, P. T., Cao, X. J., \& Mulley, C. (2012). Understanding neighbourhood design impact on travel behaviour: An application of structural equations model to a British metropolitan data.

Transportation Research Part A: Policy and Practice, 46, 22-32.

Ajzen, I. (1991). The theory of planned behavior. Organizational Behavior and Human Decision Processes, $50,179-211$.

Ahern, A., \& Hine, J. (2012). Rural transport - Valuing the mobility of older people. Research in Transportation Economics, 34(1), 27-34.

Aigner-Breuss, E., Braun, E., Schöne, M.-L., Herry, M., Steinacher, I., Sedlacek, N., Hauger, G., Klamer, M., \& Kriks, S. (2010). Mobilitätsszenarienkatalog. Mobilitätszukunft für die Generation 55+.

Mobilitätsszenarien für eine aktive Teilnahme am Verkehr unter Berücksichtigung der erforderlichen Verkehrstechnologien. Retrieved from

http://www.kfv.at/fileadmin/webcontent/Bereich VM/MOTION55 Mobilitaetsszenarienkatalog. pdf

Arber, S., \& Cooper, H. (1999). Inequalities in health in later life: The new paradox? Social Science and Medicine, 48, 61-76.

Arber, S., \& Ginn, J. (1991). Gender and later life. London: SAGE.

Armoogum, J. (Ed.), Bonsall, P., Browne, M., Christensen, L., Cools, M., Cornélis, E., Diana, M., Harder, H., Reinau, K. H.; Hubert, J.-P., Kuhnimhof, T., Madre, J.-L., Moiseeva, A., Polak, J., \& Tébar, M. (2014). Survey Harmonisation with New Technologies Improvement (SHANTI). Paris: Les collections de I'INRETS.

Bamberg, S., \& Schmidt, P. (2001). Theory-driven subgroup-specific evaluation of an intervention to reduce private car use. Journal of Applied Social Psychology, 31(6), 1300-1329.

Bamberg, S., \& Schmidt, P. (2003). Incentives, morality, or habit? Predicting students' car use for university routes with the models of Ajzen, Schwartz, and Triandis. Environment and Behavior, 35, 264-285.

Banister, D., \& Bowling, A. (2004). Quality of life for the elderly: The transport dimension. Transport Policy, $11(2), 105-115$.

Bauer, M. J., Adler, G., Kuskowski, M.A., \& Rottunda S. (2003). The influence of age and gender on the driving patterns of older adults. Journal of Women \& Aging, 15(4), 3-16.

Bell, D., Füssl, E., Ausserer, K., Risser, R., Wunsch, D., Braguti, I., Oberlader, M., \& Friedwagner, A. (2010). SZENAMO - Szenarien zukünftiger Mobilität älterer Personen. Final project report financed by the Austrian Federal Ministry for Transport, Innovation and Technology: Vienna. Retrieved from http://www2.ffg.at/verkehr/file.php?id=228

BFS \& ARE, Bundesamt für Statistik \& Bundesamt für Raumentwicklung (2007). Mobilität in der Schweiz. Ergebnisse des Mikrozensus 2005 zum Verkehrsverhalten. Retrieved from http://www.bfs.admin.ch 
Bingley, P., \& Martinello, A. (2013). Mental retirement and schooling. European Economic Review, 63, 292298.

Bonsang, E., Adam, S., \& Perelman, S. (2012). Does retirement affect cognitive functioning? Journal of Health Economics, 31, 490-501.

Cao, X. J., Handy, S., \& Mokhtarian, P. (2009). Examining the impacts of residential self-selection on travel behaviour: A focus on empirical findings. Transport Reviews, 29(3), 359-395.

Cao, X., Mokhtarian, P., L., Handy, S. L. (2007). Do changes in neighborhood characteristics lead to changes in travel behavior? A structural equations modeling approach. Transportation, 34, 535-556.

Coughlin, J. F. (2009). Longevity, lifestyle, and anticipating the new demands of aging on the transportation system. Public Works Management \& Policy, 13, 301-311.

Davidson, N. (1999). Crime and fear of crime. In M. Pacione (Ed.), Applied geography: Principles and practice (pp. 438-449). London: Routledge.

Deschryvere, M. (2005). Health and retirement decisions-An update of the literature. Discussion paper No. 932. Retrieved from http://www.etla.fi/files/1110_Dp932.pdf

Dobson, R., Dunbar, F., Smith, C.J., Reibstein, D., \& Lovelock, C. (1978). Structural models for the analysis of traveler attitude-behavior relationships. Transportation, 7, 351-363.

Dubuis, J., Weiss, D.R., \& Wolfson, C. (2007). Gender and transportation access among community-dwelling seniors. Canadian Journal on Aging, 26, 149-158.

Ellaway, A., Macintyre, S., Hiscock, R., \& Kearns, A. (2003). In the driving seat: psychosocial benefits from private motor vehicle transport compared to public transport. Transportation Research Part $F$ : Traffic Psychology and Behaviour, 6, 217-231.

Engelhardt, H., Buber, I., Skirbekk, V., \& Prskawetz, A. (2010). Social involvement, behavioural risks and cognitive functioning among older people. Ageing and Society, 30, 779-809.

Eriksson, L., \& Westin, K. (2003). När går sista bussen? Glesbygdsbors uppfattning om värdet av kollektivtrafik. Rapport 2003:01. Umeå: Umeå university, Transportforskningsenheten.

Evans, E. L. (2001). Influences on mobility among non-driving older Americans. Transportation Research Circular E-C026, 151-168.

Festinger, L. (1957). A theory of cognitive dissonance. Stanford, CA: Stanford University Press.

Figueroa, M. J., Nielsen, T. A. S., \& Siren, A. K. (2014).Comparing urban form correlations of the travel patterns of older and younger adults. Transport Policy, 35, 10-20.

Fonda, S. J., Wallace, R. B., \& Herzog, A. R. (2001). Changes in driving patterns and worsening depressive symptoms among older adults. Journals of Gerontology Series B: Psychological Sciences \& Social Sciences, 56B, 343-351. 
Frändberg, L., \& Vilhelmson, B. (2011). More or less travel: Personal mobility trends in the Swedish population focusing gender and cohort. Journal of Transport Geography 19, 1235-1244.

Golob, T. F. (2001). Joint models of attitudes and behavior in evaluation of the San Diego I-15 congestion pricing project. Transportation Research Part A, 35, 495-514.

Hakamies-Blomqvist, L., Henriksson, P., Anund, A., \& Sörensen, G. (2005). Fyrtiotalisterna som framtida äldre trafikanter. VTI rapport 507. Linköping, Sweden: VTI.

Hakamies-Blomqvist, L., \& Wahlström, B. (1998). Why do older drivers give up driving? Accident Analysis \& Prevention, 30, 305-312.

Handy, S., Cao, X., \& Mokhtarian, P. (2005). Correlation or causality between the built environment and travel behavior? Evidence from Northern California. Transportation Research Part D, 10, 427-444.

Hanson, T. R., \& Hildebrand, E. D. (2011). Can rural drivers meet their needs without a car? Stated adaptation responses from a GPS travel diary survey. Transportation, 38, 975-992.

Haustein, S. (2012). Mobility behavior of the elderly - An attitude-based segmentation approach for a heterogeneous target group. Transportation, 39, 1079-1103.

Haustein, S., \& Hunecke, M. (2007). Reduced use of environmentally friendly modes of transportation caused by perceived mobility necessities: An extension of the theory of planned behaviour. Journal of Applied Social Psychology, 37, 1856-1883.

Haustein, S., \& Hunecke, M. (2013). Identifying target groups for environmentally sustainable transport: assessment of different segmentation approaches. Current Opinion in Environmental Sustainability, 5, 197-204.

Haustein, S., Hunecke, M., \& Kemming, H. (2008). Mobilität von Senioren. Ein Segmentierungsansatz als Grundlage zielgruppenspezifischer Angebote. Internationales Verkehrswesen, 60, 181-187.

Haustein, S., \& Kemming, H. (2008). Subjektive Sicherheit von Senioren im Straßenverkehr. Zeitschrift für Verkehrssicherheit, 54, 128-133.

Haustein, S, Nielsen, T. A. S., \& Siren, A. (2014). Growing population segments and their impact on future transport. Proceedings from the Annual Transport Conference at Aalborg University, 2014. Retrieved from http://www.trafikdage.dk/papers_2014/232_SonjaHaustein.pdf

Haustein, S., \& Siren, A. (2014). Seniors' unmet mobility needs - how important is a driving licence? Journal of Transport Geography, 41, 45-52.

Hildebrand, E. D. (2003). Dimensions in elderly travel behaviour: A simplified activity-based model using lifestyle clusters. Transportation, 30, 285-306.

Hjorthol, R. (2013). Transport resources, mobility and unmet transport needs in old age. Ageing and Society, 33, 1190-1211. 
Hjorthol, R., Levin, L., \& Siren, A. (2010). Mobility in different generations of older persons. The development of daily travel in different cohorts in Denmark, Norway and Sweden. Journal of Transport Geography, 18, 624-633.

INFAS \& DLR (2010). Mobilität in Deutschland 2008, Ergebnisbericht. Bericht im Auftrag des Bundeministeriums für Verkehr, Bau und Stadtentwicklung. Bonn \& Berlin, Germany.

Kim, S. (2011). Assessing mobility in an aging society: Personal and built environment factors associated with older people's subjective transportation deficiency in the US. Transportation Research Part F: Traffic Psychology and Behaviour, 14, 422-429.

Kim, S., \& Ulfarsson, G. (2004). Travel mode choice of the elderly: Effects of personal, household, neighborhood and trip characteristics. Transportation Research Record, 1894, 117-126.

Kirchmair, R. (2005). Senioren: die heterogenste Zielgruppe von allen. Planung und Analyse, 4, 60-63.

Knight, T., Dixon, J., Warrener, M., \& Webster, S. (2007). Understanding the travel needs, behaviour and aspirations of people in later life. Report prepared for the Department of Transport. Retrieved from https://www.liftshare.com/business/pdfs/DfT-\%20later\%20life.pdf

Kolodinsky, J. M., DeSisto, T. P., Propen, D., Putnam, M. E., Roche, E., \& Sawyer, W.R. (2013). It is not how far you go, it is whether you can get there: modelling the effects of mobility on quality of life in rural New England. Journal of Transport Geography, 31, 113-122.

Köpke, S., Deubel, K., Engeln, A., \& Schlag, B. (1999). Mobilitätswahrnehmung und Selbstbild von älteren Autofahrern. In B. Schlag (Ed.), Empirische Verkehrspsychologie (pp. 159-175). Lengerich: Pabst Science Publishers.

Kuhnimhof, T., Armoogum, J., Buehler, R., Denstadli, J. M., \& Yamamoto, T. (2012). Men shape a downward trend in car use among young adults-Evidence from six industrialized countries. Transport Reviews: A Transnational Transdisciplinary Journal, 32(6), 761-779.

Kuhnimhof, T., Buehler, R., Wirtz, M., \& Kalinowska, D. (2012). Travel trends among young adults in Germany: increasing multimodality and declining car use for men. Journal of Transport Geography, $24,443-450$.

Kunert, U. (1994). Singles: Zahlreich und mobil. Zum Mobilitätsverhalten alleinlebender Personen. In S. Gräbe (Ed.), Lebensform Einpersonenhaushalt: Herausforderungen an Wirtschaft, Gesellschaft und Politik (pp. 133-158). Frankfurt a. M.: Campus.

Lang, I. A., Llewellyn, D. J., Langa, K. M., Wallace, R. B., Huppert, F. A., \& Melzer D. (2008). Neighborhood deprivation, individual socioeconomic status, and cognitive function in older people: Analyses from the English Longitudinal Study of Ageing". Journal of the American Geriatrics Society, 56, 191-198.

Lanzieri, G. (2011). The greying of the baby boomers. A century-long view of ageing in European populations. Eurostat: Statistics in focus, 23/2011. Retrieved from http://epp.eurostat.ec.europa.eu/cache/ITY OFFPUB/KS-SF-11-023/EN/KS-SF-11-023-EN.PDF 
Le Vine, S., \& Jones, P. (2012). On the move. Making sense of car and train travel trends in Britain. RAC Foundation, London. Retrieved from http://www.racfoundation.org/assets/rac_foundation/content/downloadables/on_the_movele_vine_\&_jones-dec2012.pdf

Li, H., Raeside, R., Chen, T., \& McQuaid R. W. (2012). Population ageing, gender and the transportation system. Research in Transportation Economics, 34, 39-47.

Mandl, B., Millonig, A., \& Friedl, V. (2013, January). The variety of the golden agers: Identifying profiles of older people for mobility research. Poster presented at the Transportation Research Board 92nd Annual Meeting, Washington.

Macintyre, S., Hiscock, R., Kearns, A., \& Ellaway, A. (2001). Housing tenure and car access: Further exploration of the nature of their relation with health in a UK setting. Journal of Epidemiology and Community Health, 52, 657-664.

Marin-Lamellet, C., \& Haustein, S. (2014). Managing the safe mobility of older road users: how to cope with their diversity? Journal of Transport \& Health. Advance online publication. doi: 10.1016/j.jth.2014.07.006

Marottoli, R., Mendes de Leon, C., Glass, T., Williams, C., Cooney, L. J., Berkman, L. F., \& Tinetti, M. (1997). Driving cessation and increased depressive symptoms: prospective evidence from the New Haven EPESE. Established Populations for Epidemiologic Studies of the Elderly. Journal of American Geriatric Society, 45, 202-206.

Mazzonna, F., \& Peracchi, F. (2012). Ageing, cognitive abilities and retirement. European Economic Review, 45, 691-710.

Menec, V. H. (2003). The relation between everyday activities and successful aging: A 6-year longitudinal study. Journal of Gerontology, B, 58(2), S74-S82. doi: 10.1093/geronb/58.2.S74

Mollenkopf, H. (2002). Die Mobilität Älterer in städtischen und ländlichen Regionen Ost- und Westdeutschlands. In B. Schlag \& K. Megel (Eds.), Mobilität und gesellschaftliche Partizipation im Alter. Schriftenreihe des BFSFJ, Band 230 (pp. 130-146). Stuttgart: Kohlhammer.

Mollenkopf, H., Marcellini, F., Ruoppila, I., Szeman, Z., Tacken, M., \& Wahl, H.-W. (2004). Social and behavioural science perspectives on out-of-home mobility in later life: Findings from the European project MOBILATE. European Journal of Ageing, 1, 45-53.

Musselwhite, C. (2010). The role of education and training in helping older people to travel after the cessation of driving. International Journal of Education and Ageing, 1(2), 197-212.

Nilsson, C. J., Avlund, K., \& Lund, R. (2011). Onset of mobility limitations in old age: The combined effect of socioeconomic position and social relations. Age and Ageing, 40, 607-614.

OECD (2001). Ageing and Transport: Mobility needs and safety issues. Paris: OECD 
Pain, R. H. (1997). 'Old age' and ageism in urban research: The case of fear of crime. International Journal of Urban and Regional Research, 21, 117-128.

Pucher, J. \& Buehler, R. (2008). Making cycling irresistible: Lessons from The Netherlands, Denmark and Germany. Transport Reviews, 28, 495-528.

Rohwedder, S., \& Willis, R. J. (2010). Mental retirement. Journal of Economic Perspectives, 24, 119-138.

Rosenbloom, S. (2006). Is the driving experience of older women changing? Safety and mobility consequences. Transportation Research Record, 1956, 127-132.

Rosenbloom, S., \& Winsten-Bartlett, C. (2002). Asking the right question - Understanding the travel needs of older women who do not drive. Transportation Research Record, 1818, 78-82.

Scheffer, A. C., Schuurmans, M. J., van Dijk, N., van der Hooft, T., \& de Rooij, S. E. (2008). Fear of falling: measurement strategy, prevalence, risk factors and consequences among older persons. Age and Ageing, 37(1), 19-24.

Scheiner, J. (2004). Macht Mobilität glücklich? Auswirkungen der Mobilität auf die Lebenszufriedenheit. In: G. Rudinger, C. Holz-Rau, \& R. Grotz (Eds.), Freizeitmobilität älterer Menschen. Dortmunder Beiträge zur Raumplanung (pp. 173-179). Dortmund, Germany: IRPUD.

Scheiner, J. (2006). Does the car make elderly people happy and mobile? Settlement structures, car availability and leisure mobility of the elderly. European Journal of Transport and Infrastructure Research, 2, 151-172.

Scheiner, J., \& Holz-Rau, C. (2007). Travel mode choice: affected by objective or subjective determinants? Transportation, 34, 487-511.

Schwanen, T., Dijst, M., \& Dieleman, F. M. (2001). Leisure trips of senior citizens: Determinants of modal choice. Tijdschrift voor Economische en Sociale Geografie, 92(3), 347-360.

SHARE project (2014). Survey of Health, Ageing and Retirement in Europe. Data Access and Documentation. Retrieved from http://www.share-project.org/data-access-documentation.html

Shergold, I., Lyons, G., \& Hubers, C. (2014). Future mobility in an ageing society - Where are we heading? Journal of Transport \& Health. Advance online publication. doi:10.1016/j.jth.2014.10.005

Siegrist, J., \& Wahrendorf, M. (2009). Participation in socially productive activities and quality of life in early old age: findings from SHARE. Journal of European Social Policy 19, 317-326.

Siren, A., \& Hakamies-Blomqvist, L. (2004). Private car as the grand equaliser? Demographic factors and mobility in Finnish men and women aged 65+. Transportation Research Part F: Traffic Psychology and Behaviour, 7, 107-118.

Siren, A., \& Hakamies-Blomqvist, L. (2006). Does gendered driving create gendered mobility? Communityrelated mobility in Finnish women and men aged 65+. Transportation Research Part F: Traffic Psychology and Behaviour, 9, 374-382. 
Siren, A., \& Hakamies-Blomqvist, L. (2009). Mobility and well-being in old age. Topics in Geriatric Rehabilitation, 25(1), 3-11.

Siren, A., Hakamies-Blomqvist, L., \& Lindeman, M. (2004). Driving cessation and health in older women. Journal of Applied Gerontology, 23, 58-69.

Siren, A., \& Haustein, S. (2013). Baby boomers' mobility patterns and preferences: What are the implications for future transport? Transport Policy, 29, 136-144.

Siren, A., \& Haustein, S. (2014a, May). How does baby boomers' transport mobility change with retirement? Poster presented at 22nd Nordic Congress of Gerontology, Gothenburg, Sweden.

Siren, A., \& Haustein, S. (2014b). Driving Cessation Anno 2010: Which older drivers give up their licence and why? Evidence from Denmark. Journal of Applied Gerontology. Advance online publication. doi: http://dx.doi.org/10.1177/0733464814521690

Siren, A., \& Haustein, S. (2014c). What are the impacts of giving up the driving licence? Ageing and Society. Advance online publication. doi:10.1017/S0144686X14000610

Siren, A., \& Haustein, S. (2014d). Driving licences and medical screening in old age. Review of literature and European licensing policies. Journal of Transport \& Health. Advance online publication. doi: http://dx.doi.org/10.1016/j.jth.2014.09.003

Smith, G. C., \& Sylvestre, G. M. (2001). Determinants of the travel behavior of suburban elderly. Growth Change, 32, 395-412.

Ståhl, A., Horstmann, V., \& Iwarsson, S. (2013). A five-year follow-up among older people after an outdoor environment intervention. Transport Policy, 27, 134-141.

Su, F., \& Bell, M. G. H. (2009). Transport for older people: Characteristics and solutions. Research in Transportation Economics, 25, 46-55.

Tacken, M. (1998). Mobility of the elderly in time and space in the Netherlands: An analysis of the Dutch National Travel Survey. Transportation, 25, 379-393.

Transek (2005). Äldre personers resvanor och aktiviteter. Resultat från undersökningar med personer $i$ åldern 65 år och äldre. Rapport 2005:23. Stockholm: Transek.

TØI, Transportøkonomisk institutt (2011). Den nasjonale reisevaneunders $\emptyset$ kelsen 2009 - nøkkelrapport. Oslo: Transportøkonomisk institutt.

Waara, N., \& Stjernborg, V. (2010, June). Mobility of older women and men at transition from a two person household to a one person household. Paper presented at the 12th International Conference on Mobility and Transport for Elderly and Disabled Persons (TRANSED 2010), Hong Kong.

Watts, A. S., Ferdous, F., Diaz Moore, K., \& Burns, J. M., (2014). Neighborhood integration and connectivity predict cognitive decline in older adults with and without Alzheimer's disease. Manuscript submitted for publication. 
Wedel, M., \& Kamakura, W. A. (Eds.) (1998). Market segmentation: Conceptual and methodological foundations. Boston: Kluwer Academic Publisher. 
Table 1: Segmentation studies included in this review

\begin{tabular}{|c|c|c|c|c|c|}
\hline \multirow{2}{*}{$\begin{array}{l}\text { Study } \\
\text { author, year } \\
\text { (project title) }\end{array}$} & \multicolumn{3}{|c|}{ Sample characteristics } & \multirow[t]{2}{*}{ Segmentation method } & \multirow[t]{2}{*}{ Variables used for segmentation } \\
\hline & $N$ & Age range & Region & & \\
\hline $\begin{array}{l}\text { Aigner-Breuss et al., } \\
2010 \text { (MOTION 55+) }\end{array}$ & 402 & $55+$ & $\begin{array}{l}\text { Selected rural communes in Austria } \\
\text { (18 communes in the } \\
\text { "Wienerwald" region) }\end{array}$ & a priori / rules & $\begin{array}{l}\text { Access to a car; use of different } \\
\text { transport modes }\end{array}$ \\
\hline $\begin{array}{l}\text { Bell et al., } 2010 \\
\text { (SZENAMO) }\end{array}$ & 1500 & $62-95$ & $\begin{array}{l}\text { Austria, } \\
50 \% \text { Vienna; 50\% state } \\
\text { "Burgenland" }\end{array}$ & Cluster analysis & $\begin{array}{l}\text { Health; household structure; } \\
\text { employment status }\end{array}$ \\
\hline Haustein, 2012 & 1500 & $60+$ & $\begin{array}{l}\text { Germany, state North Rhine- } \\
\text { Westphalia (variety of urban areas) }\end{array}$ & Cluster analysis & $\begin{array}{l}\text { Income; car availability; social } \\
\text { network size; accessibility; } \\
\text { transport attitudes }\end{array}$ \\
\hline $\begin{array}{l}\text { Haustein et al., } 2008 \\
\text { (MOBILANZ) }\end{array}$ & 557 & $60+$ & $\begin{array}{l}\text { Germany, cities of Augsburg, } \\
\text { Bielefeld, Magdeburg (in each city } \\
\text { an inner-city district, a city border } \\
\text { district, and a suburban district) }\end{array}$ & Cluster analysis & $\begin{array}{l}\text { Age; number of cars; transport } \\
\text { attitudes }\end{array}$ \\
\hline Hildebrand, 2003 & 1150 & $65+$ & Portland, Oregon, US & Cluster analysis & $\begin{array}{l}\text { Socio-demographics variables (e.g., } \\
\text { age, income, licensed) }\end{array}$ \\
\hline $\begin{array}{l}\text { Mandl et al., } 2013 \\
\text { (GOAL) }\end{array}$ & 55,000 & $50+$ & $\begin{array}{l}20 \text { European Countries } \\
\text { (SHARE database) }\end{array}$ & Cluster analysis & Demographics and health \\
\hline $\begin{array}{l}\text { Mollenkopf et al., } 2004 \\
\text { (MOBILATE) }\end{array}$ & 3934 & $55+$ & $\begin{array}{l}\text { Finland; Germany; Hungary; Italy; } \\
\text { Netherlands }\end{array}$ & Cluster analysis & $\begin{array}{l}\text { Trip frequency; variety of used } \\
\text { transport options; variety of trip } \\
\text { purposes; mobility satisfaction }\end{array}$ \\
\hline Siren \& Haustein, 2013 & 1772 & $62-63$ & Denmark (random sample) & Cluster analysis & $\begin{array}{l}\text { Expectations regarding future } \\
\text { transport mode use; mobility and } \\
\text { dependency }\end{array}$ \\
\hline
\end{tabular}


Table 2: Characteristics of the segments identified in the studies in Table 1

\begin{tabular}{|c|c|c|c|c|c|c|c|}
\hline Segments & $\begin{array}{l}\text { Group of } \\
\text { segments }\end{array}$ & $\begin{array}{l}\text { Mobility } \\
\text { patterns }\end{array}$ & Car use & $\begin{array}{c}\text { Activity } \\
\text { level }\end{array}$ & $\begin{array}{l}\text { Socio- } \\
\text { economic } \\
\text { resources }\end{array}$ & Health & Male \\
\hline Affluent mobiles $^{3}$ & \multirow{9}{*}{$\begin{array}{l}\text { Affluent } \\
\text { mobile } \\
\text { drivers }\end{array}$} & \multirow{9}{*}{$\begin{array}{l}\text { Predominant } \\
\text { car use, high } \\
\text { activity } \\
\text { engagement }\end{array}$} & + & + & + & + & + \\
\hline Mobile car-oriented ${ }^{3 \mathrm{~A}}$ & & & + & + & + & + & + \\
\hline Workers ${ }^{4}$ & & & + & + & + & + & + \\
\hline Affluent males ${ }^{4}$ & & & + & + & + & + & + \\
\hline Fit as a fiddle ${ }^{5}$ & & & + & + & + & + & + \\
\hline Happily connected $^{5}$ & & & + & + & + & + & + \\
\hline Independents $^{7}$ & & & + & + & + & + & + \\
\hline Fully mobile seniors ${ }^{2}$ & & & + & + & $t^{a}$ & + & 0 \\
\hline Subgroup $1^{6}$ & & & + & + & + & + & 0 \\
\hline Predominant car users ${ }^{1}$ & & & + & 0 & 0 & 0 & 0 \\
\hline Mobile widows ${ }^{4}$ & & & + & 0 & - & + & - \\
\hline Captive car users ${ }^{3}$ & \multirow{4}{*}{$\begin{array}{l}\text { - Car } \\
\text { - dependent } \\
\text { seniors }\end{array}$} & \multirow{4}{*}{$\begin{array}{l}\text { Predominant } \\
\text { car use, low } \\
\text { activity } \\
\text { engagement }\end{array}$} & + & - & - & - & 0 \\
\hline Mobility impaired ${ }^{3 A}$ & & & + & - & - & - & 0 \\
\hline Hole in the heart ${ }^{5}$ & & & + & - & - & - & 0 \\
\hline Disabled drivers $^{4}$ & & & + & - & - & - & - \\
\hline Subgroup $2^{6}$ & \multirow{9}{*}{$\begin{array}{l}\text { Mobile } \\
\text { multi-modal } \\
\text { seniors }\end{array}$} & \multirow{9}{*}{$\begin{array}{l}\text { Use of all } \\
\text { modes; high/ } \\
\text { medium } \\
\text { activity } \\
\text { engagement }\end{array}$} & 0 & + & + & + & 0 \\
\hline Self-determined mobiles ${ }^{3 \mathrm{~A}}$ & & & 0 & + & 0 & 0 & 0 \\
\hline Flexibles $^{7}$ & & & 0 & 0 & + & 0 & 0 \\
\hline Selective car users ${ }^{1}$ & & & - & + & + & + & 0 \\
\hline An Oldie but a goodie ${ }^{5}$ & & & - & + & + & 0 & - \\
\hline Self-determined mobiles ${ }^{3}$ & & & - & + & 0 & + & 0 \\
\hline Bike-oriented $^{3 \mathrm{~A}}$ & & & - & + & 0 & + & 0 \\
\hline Ecology-minded PT-users ${ }^{3 \mathrm{~A}}$ & & & - & + & - & 0 & - \\
\hline Slightly impaired seniors ${ }^{2}$ & & & - & 0 & $0^{\mathrm{a}}$ & 0 & 0 \\
\hline Pragmatic PT-oriented ${ }^{3 \mathrm{~A}}$ & & & - & 0 & - & - & 0 \\
\hline Captive PT users ${ }^{3}$ & & & - & 0 & - & - & - \\
\hline Granny flats ${ }^{4}$ & \multirow{8}{*}{$\begin{array}{l}\text { Transport } \\
\text { service } \\
\text { dependent } \\
\text { seniors }\end{array}$} & \multirow{8}{*}{$\begin{array}{l}\text { Walking, } \\
\text { public } \\
\text { transport \& } \\
\text { car use as } \\
\text { passenger; } \\
\text { low activity } \\
\text { engagement }\end{array}$} & - & - & $t^{\mathrm{b}}$ & - & - \\
\hline Subgroup $3^{6}$ & & & - & - & - & 0 & - \\
\hline Persons without a car ${ }^{1}$ & & & - & - & - & - & - \\
\hline Highly impaired seniors ${ }^{2}$ & & & - & - & $-\mathrm{-a}^{\mathrm{a}}$ & - & - \\
\hline Mobility impaired $^{4}$ & & & - & - & - & - & - \\
\hline The care-full ${ }^{5}$ & & & - & - & - & - & - \\
\hline Subgroup $4^{6}$ & & & - & - & - & - & - \\
\hline Restricted $^{7}$ & & & - & - & - & - & - \\
\hline
\end{tabular}


Notes. ${ }^{1}$ Aigner-Breuss et al. (2010); ${ }^{2}$ Bell et al. (2010); ${ }^{3}$ Haustein (2012); ${ }^{3 A}$ Haustein et al. (2008); ${ }^{4}$ Hildebrand (2003); ${ }^{5}$ Mandl et al. (2013); ${ }^{6}$ Mollenkopf et al. (2004); Siren \& Haustein (2013); + above average; 0 average;

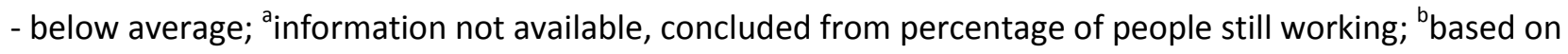
household income, but person is not the household head. 